\title{
Assessment of the implementation of the infectious diseases screening programmes among pregnant women in the Lesser Poland region and comparison with similar programmes conducted in other European Union countries
}

\author{
Małgorzata Radoń-Pokracka, Maciej Piasecki, Alicja Lachowska, Sebastian Baczkowski, \\ Joanna Spaczyńska, Magdalena Górecka, Magdalena Nowak, Hubert Huras \\ Department of Obstetrics and Gynecology, Jagiellonian University Medical College in Krakow, Poland
}

\begin{abstract}
Objectives: The aim of the study was to assess the level of implementation of recommendations of the Ministry of Health regarding infectious disease screening during pregnancy.

Material and methods: The study included 477 patients who were admitted to the delivery room between December 2015 and February 2016. Data on screening test results were collected based on medical records covering the period before the admission.

Results: The Human Immunodeficiency Virus (HIV) screening was conducted in 410 (86\%). 460 (96\%) of patients were screened for Hepatitis B Virus (HBV) and 427 (89.5\%) for Hepatitis C Virus (HCV). Syphilis screening covered 465 (97.5\%) of patients. Immunoglobulin M (IgM) titer against Rubella Virus (RV) was assessed in 218 (45\%) patients and immunoglobulin G (lgG) in 319 (66.9\%). Screening for Toxoplasma gondii based on assessment of IgM titer was conducted in 440 (92\%) patients while IgG titter was assessed in 413 (86.6\%). 343 (71.9\%) patients had obtained vaginal swabs for Group B Streptococci (GBS) while the anal swabs were taken only from 268 (56.2\%) patients.

Conclusions: Coverage of screening for syphilis and HBV was similar to the countries with highest prevalence of conducting such screening, on the other hand RV screening place as among countries with lowest prevalence. There is an increasing trend in conducting HIV screening. Screening for HCV and toxoplasmosis is at satisfactory level and Poland is one of a few European countries offering such screening. The screening for GBS is insufficient which result in excessive use of intrapartum antibiotic prophylaxis.
\end{abstract}

Key words: prenatal care, infectious diseases in pregnancy, screening programmes

Ginekologia Polska 2017; 88, 3: 151-155

\section{INTRODUCTION}

The recommendation regarding the antenatal care issued by the Minister of Health of Poland on 20 September 2012 specifies the standards of care for the pregnant women during physiological pregnancy, childbirth and postpartum period. An important part of the guidelines are recommendations for the screening of pregnant women for certain infectious diseases that may constitute a threat to the physiological course of pregnancy or to the foetus [1]. According to the guidelines, every pregnant women up to $10^{\text {th }}$ weeks of pregnancy should have been screened for Human Immunodeficiency Virus (HIV), Treponema pallidum infection that causes syphilis and Hepatitis C Virus (HCV). Moreover the immunoglobulin $\mathrm{M}$ ( $\lg \mathrm{M}$ ) and immunoglobulin G (lgG) titer against the Rubella Virus (RV) and Toxoplasma gondii (T. gondii) should be determined (in case of a negative 
results, the test for $T$. gondii should be repeated between $21^{\text {st }}$ and $26^{\text {th }}$ weeks of gestation). Between $33^{\text {rd }}$ and $37^{\text {th }}$ weeks of gestation the Hepatitis B Virus (HBV) screening should be carried out as well as vagina and anal swabs for the Streptococcus agalactiae which are classified by Lancefield classification as a Group B Streptococci (GBS) [1]. Additionally the HIV screening should be repeated, and among patients with an increased population or individual risk the tests for T. pallidum and HCV as well [1]. The establishing of nationwide guidelines for the Polish population is part of a pan-European trend aimed at reducing the incidence of mother-to-child transmission (MTCT) and congenital syndromes. The report prepared by the European Centre for Disease Prevention and Control (ECDC) compares the individual EU member states recommendation for the infectious disease screening during pregnancy as well as the degree of their implementation. Out of 26 countries including Poland, 25 (except for Hungary) has national guidelines on the screening of pregnant women for infectious diseases [2]. Recommendations for specific infection diseases covered by the guidelines as well as to the time and manner of conducting the screening differ between countries. Testing for syphilis is recommended in all the countries included in the survey, while HIV testing is recommended in 24 countries (except for Hungary and Slovenia), HBV screening in 23 countries (except Lithuania, Norway and Romania), and RV screening in 17 countries (except for Denmark, Estonia, Finland, Hungary, Lithuania, Latvia, the Netherlands, Romania and Slovenia) [2]. The report prepared by the ECDC did not cover the screening tests policies for HCV, T. gondii and GBS [2].

\section{OBJECTIVES}

The aim of the study was to assess the level of implementation of recommendations of the Ministry of Health regarding infectious disease screening during pregnancy [1]. So far, there were no overall assessment conducted for the Polish population.

\section{MATERIAL AND METHODS}

The study included patients who were admitted to the delivery room of the third level perinatal center between December 2015 and February 2016. On a given period of time we collect the data from 477 patients. Antenatal infectious diseases screening in Poland is mainly held by the out-patient services but all the obtained results should be properly noted in the Personal Maternity Record. Moreover patients had the original laboratory results as a part of their own medical records. Patients are free to choose provider where the tests are conducted thus in our research the specific laboratory characteristics of the single tests are lacking. In our research we studied the Personal Maternity
Records and all the lab test results that patients bring to the admission room in search of the laboratory results. Data on screening test results cover the period before the admission to the delivery room and if the patient did not have the result of any of the recommended screening tests, the test was commissioned during hospital admission, but the result was not taken into account in the present study.

\section{RESULTS}

Taking into account that we included all the patients admitted to the delivery room between studied period there were no important differences in baseline characteristics (age, education status, number of pregnancies and place of living) between the groups of patients who had or had not the screening test results. 410 (86\%) patients had at least once during pregnancy performed tests for HIV, all the results were negative. The HBV screening was performed in 460 (96\%) patients with 4 positive results, while for HCV 427 (89.5\%) patients were tested with 2 positive results. Screening for syphilis which included 465 (97.5\%) patients and resulting in only negative results was the most often performed test in our research. In turn, the least likely performed test was the lgM titer against the RV, which was performed in 218 (45\%) patients with 2 positive results. The IgG titer against RV was determined in 319 (66.9\%) patients, and the majority of them - 301 (94\%) had reached protective antibody levels. IgM against Toxoplasma gondii was determined in 440 (92\%) patients of whom 3 had positive results, while IgG titer was assessed in 413 (86.6\%) patients and give mostly negative result - 330 (80\%). 343 (71.9\%) patients had the vaginal swab for GBS obtained, but the rectal swabs were collected only from 268 (56.2\%) patients. 131 (27.5\%) patients admitted to the delivery rooms did not have any swabs taken during the pregnancy. Vaginal swabs were positive in 85 (25\%) patients, and rectal swabs in 68 (25.4\%). 192 (40\%) patients had both swabs negative.

\section{DISCUSSION}

The report prepared by the ECDC declare that among the 18 countries that provided information on the prevalence of screening for HIV during pregnancy, the majority $(12 / 18)$ reported a $95 \%$ or a higher percentage of patients who had performed test at least once during the pregnancy. The Polish data provided for the ECDC report came from the document prepared by the Team for Implementation of the National Program for Prevention of HIV and Combating AIDS in Mazowieckie [3]. Based on health records of 1111 pregnant women included in the survey, the test for HIV were not performed in 370 (33.3\% ) patients [3]. In our group, the percentage of women who did not have screening for HIV during pregnancy was $14 \%$. Despite significant improvements in testing for HIV during pregnancy 
Table 1. Number of patients covered by the screening with the results

\begin{tabular}{|c|c|c|c|}
\hline & $\begin{array}{l}\text { Number }(\%) \text { of patiend } \\
\text { undergoing screening }\end{array}$ & Number (\%) of negative results & Number (\%) of positive results \\
\hline HIV & $410(86 \%)$ & $410(100 \%)$ & 0 \\
\hline HBV & $460(96 \%)$ & $456(99 \%)$ & $4(1 \%)$ \\
\hline $\mathrm{HCV}$ & $427(89.5 \%)$ & 425 (99.5\%) & $2(0.5 \%)$ \\
\hline Syphilis & $465(97.5 \%)$ & $465(100 \%)$ & 0 \\
\hline \multicolumn{4}{|l|}{ Rubella Virus } \\
\hline $\lg M$ & $218(45 \%)$ & $216(99 \%)$ & $2(1 \%)$ \\
\hline $\lg G$ & $319(66.9 \%)$ & $18(6 \%)$ & $301(94 \%)$ \\
\hline \multicolumn{4}{|c|}{ Toxoplasma gondii } \\
\hline $\lg M$ & $440(92 \%)$ & $437(99.3 \%)$ & $3(0.7 \%)$ \\
\hline $\lg G$ & $413(86.6 \%)$ & $330(80 \%)$ & $83(20 \%)$ \\
\hline \multicolumn{4}{|l|}{ S. agalactiae } \\
\hline Vaginal swab & $343(71.9 \%)$ & $258(75 \%)$ & $85(25 \%)$ \\
\hline Anal swab & $268(56.2 \%)$ & $200(74.6 \%)$ & $68(25.4 \%)$ \\
\hline
\end{tabular}

HIV — Human Immunodeficiency Virus; HBV — Hepatitis B Virus; HCV — Hepatitis C Virus

in relation to the data presented in the report from 2013, Poland compared to other European Union countries still has a much lower percentage of patients undergoing the screening. Mother-to-child transmission (MTCT) is the major cause of HIV infection among children [4]. It should be noted that, according to the data from Polish National Institute of Public Health only in 2015 there were 184 women newly diagnosed with HIV mostly in reproductive age -158 patients (86\%) between the age 15 to 49 [5]. In addition, in 2015 the HIV infection occurred in 5 newborns which clearly shows the gaps in the screening [5]. Detection of the virus during pregnancy allows the patient to undergo an appropriated treatment. Reduction of the viral load below 50 copies $/ \mathrm{mL}$, implementation of highly active antiretroviral therapy and the abandonment of breastfeeding reduces the risk of vertical transmission to 1-2\% [6]. Those goals could be only achieved when the positive serological status of the pregnant women is known during the pregnancy. Modern HIV screening is based on the III ${ }^{\text {rd }}$ and IVth generation test that detect the antibodies or antibodies and p24 antigen of the HIV.

HBV screening is carried out in 23 European Union countries covered by the ECDC report except Lithuania, Romania and Norway. In most countries, including Poland screening is based on detection of Hepatitis B surface antigen - HBsAg [2]. Poland did not have data on the prevalence of screening for the presence of HBsAg, however, among the 13 countries that provided such data 8 determined the prevalence of screening at a level exceeding 95\% [2]. In the presented results the determination of $\mathrm{HBsAg}$ was performed in $96 \%$ of patients, which places our studied population among countries with a high percentage of patients who were screened for HBV. The risk of vertical transmission depends on the serological status of the pregnant woman infected with $\mathrm{HBV}$. It is highest in the presence of $\mathrm{HBsAg}$ and $\mathrm{HBeAg}$ antigen in the blood - 70-90\%, while the presence of only $\mathrm{HBsAg}$ reduce the risk of vertical transmission to $15 \%[7,8]$. Due to the fact that there is a high risk of vertical transmission it is necessary to conduct screening for HBV infection among pregnant women, because it enables the implementation of appropriate treatment for newborn which largely prevents the infection in the chronic form. The only available method of prevention of neonatal infection is the administration of the vaccine and specific immunoglobulin. The effectiveness of such treatment is estimated at 90\% [9].

ECDC report does not include data on the screening for $\mathrm{HCV}$ in the population of pregnant patients. There is also lack of extensive research on the prevalence of HCV infection in the population of pregnant patients in Poland. Aniszewska et al. in their work evaluated the prevalence of HCV in the population of 544 pregnant women at $2.02 \%$ [10]. So far there are no data on the prevalence of screening for $\mathrm{HCV}$ in the population of pregnant women, which is recommended by the Minister of Health [1]. In the population of patients included in our research HCV screening was commissioned in 427 (89\%) patients, giving 2 (0.5\%) positive results. Vertical transmission is the most common route of transmission of $\mathrm{HCV}$ in the population of infants and children. The risk of transmission of virus is estimated to be $1.8-5 \%$ [11]. Currently there is no treatment options for women infected with HCV during pregnancy because all the schemes are based on ribavirin, which has a strong teratogenic effect. Therefore, current screening for HCV in the population of pregnant patients aims at selecting a group of patients 
infected with the virus so it would be possible to provide specialised neonatal care for their children.

T. pallidum is a Gram-negative bacteria which is the etiological agent of syphilis. The risk of vertical transmission largely depends on the viral load, and thus the stage of the disease. In the case of early syphilis risk of foetal infection range from $70 \%$ to $100 \%$, early latent syphilis - $40 \%$, and late syphilis - 10\% [8]. The most effective antibiotic treatment of syphilis is penicillin, which can be successfully used also during pregnancy. Effective treatment of syphilis using penicillin reduces the risk of vertical transmission to 1-2\% [12], thus the screening allows us to select pregnant patients with syphilis and treat them during pregnancy which results in better maternal and neonatal outcomes but also breaks the transmission route. Untreated syphilis in pregnancy may cause intrauterine foetal death or miscarriage and the birth of a living child may result in the occurrence of early or late congenital syphilis [8]. The report prepared by the ECDC acclaims that test for syphilis during pregnancy is recommended in all countries, but data on its course and results were provided only by the 24 countries, except for Portugal and Poland [2]. In Poland, the screening is based on the Venereal Disease Research Laboratory (VDRL) test, which is a non-treponemal test, so every positive result requires confirmation with the treponemal test [13]. For the 18 countries that provided information on the extent of screening 14 has determined that the test for syphilis was performed at least once during pregnancy in 95\% of patients [2]. In our population the screening for syphilis was the most often ordered test and covered 465 (97.5\%) patients, while giving only negative results.

The last screening test evaluated in the report prepared by the ECDC was a test assessing the immunisation of the population of pregnant patients against RV. Serological screening for presence of antibodies against RV is recommended in 14/26 countries participating in the report. There is no data on the percentage of women covered by the screening. According to Polish recommendations, each pregnant woman should have checked the IgM titer, which testify to the fresh or recent infection and IgG titer, which testify to the past illness or vaccination and provide durable resistance $[1,8]$. This enables the identification of a group of patients who are not immune to RV infection during pregnancy. Having data on the serological status of patients in the early stages of pregnancy also allows more accurate interpretations of repeated serological tests performed in the case of contact with RV during later stage of pregnancy. Infection before 16 weeks of gestation is associated with the risk of congenital rubella syndrome, which is characterised by sensorineural deafness, eye abnormalities and congenital heart disease (Gregg triad) [14]. In the studied population the IgM were identified in 218 (45\%) patients, and IgG in 319 (66.9\%) patients. Serological test for RV was the least likely performed screening among pregnant patients. The percentage of patients who had positive titer of IgG and so were immune against RV was 94\% (301). The paper by Janaszek-Seydlitz et al. published in 2003 assessed 1.289 samples of blood from women aged 15-30 from 6 provinces of Poland for presence of $\mathrm{lg} G$ against rubella with $89.5 \%$ of positive results, which is similar to that obtained in our research [15].

T. gondii infection occurs mostly through the consumption of raw meat containing cysts or unwashed vegetables or fruits contaminated with oocysts which are the result of sexual reproduction of the parasite in cats [16]. Infection during pregnancy carries a risk of miscarriage as well as the development of defects affecting the nervous system and eyes [17]. Diagnosis of T. gondii infection during pregnancy only on the basis of clinical signs is extremely difficult because $90 \%$ of infections are asymptomatic [18] and therefore an important point in the prevention of congenital toxoplasmosis is screening based on a determination of IgM and IgG titer. In the study population 440 (92\%) patients were evaluated for IgM titer of which $99.3 \%$ were negative. The IgG titer were determined in 413 (86.6\%) patients in whom $80 \%$ of the results were negative, and thus this group of patients had no previous contact with the parasite which forms a risk for the development of infection during pregnancy. The paper by Nowakowska et al. published in 2006 shows that in population of 4916 patients aged 19-46 enrolled to the study between 1998 and 2003, only $41.3 \%$ had positive antibody lgG titer against T. gondii [19]. Our work has shown that the observable trend is to further reduce the number of pregnant patients who had have contact with $T$. gondii in favour of patients susceptible to the development of infection during pregnancy.

Streptococcus agalactiae is the Gramm-positive bacteria that physiologically colonise the lower gastrointestinal tract and the genitourinary system. S. agalactiae colonisation of the neonate during delivery, which occurs in $70 \%$ of cases, may result in the development of lower respiratory tract infections, sepsis and meningitis. It is estimated that mortality due to $S$. agalactiae infections among newborns is up to $20 \%$ [20]. The use of an appropriate intrapartum antibiotic prophylaxis based on penicillin $\mathrm{G}$ or ampicillin reduces the risk of the disease in newborn. Screening for GBS is based on the vaginal and anal swabs. In the case of any positive result, or lack of the screening the patient requires the implementation of intrapartum antibiotic prophylaxis. Testing for GBS colonisation during pregnancy is particularly important not only because of the possibility of effective intrapartum antibiotic prophylaxis, but also because of the possibility to avoiding it, when both swabs from are negative [21]. In the study 343 (71.9\%) patients 
had obtained vaginal swab, while rectal swab were taken only in 268 (56.2\%) patients. 131 (27.5\%) patients had not taken any of the swabs, which implicates the need to use antibiotics. Based on the vaginal swabs the colonisation is estimated at $25 \%$ in turn, rectal colonisation occurs in $25.4 \%$ of patients. A study conducted between 2001 and 2002 at the Department of Obstetrics and Gynaecology Institute of Mother and Child in Warsaw showed that in a group of 1.678 pregnant women the presence of group B streptococci were found in 331 (19.7\%) patients [22]. On the other hand, a study conducted by the Brzychczy-Włoch et al. showed that in 2004-2005 colonisation of women with normal pregnancies was $17.2 \%$, while the colonisation in high risk pregnancy was $20 \%$ [23]. The data obtained in the present study indicate a further increase in the incidence of GBS colonisation in the population of pregnant patients.

Our study has several limitations. First, we investigate the implementation of the recommendation only in a population of patients admitted to the single III ${ }^{\text {rd }}$ level perinatal center, which is a referral hospital for all highly complicated pregnancy in the Lesser Poland region. Even though there were no significant differences in our study population in maternal comorbidity, there is a risk that our group represents part of the general population of pregnant women that were especially monitored during pregnancy, because of their high risk status. On the other hand the fact that the patients included in the study were from different parts of the region provide a high diversity. Secondly, because the antenatal screening is carried out in the out-patient services, we do not have the data on the quality of the conducted screening test and their results, thus our paper does not focus at evaluating the effectiveness of the screening programmes.

\section{CONCLUSIONS}

Screening for syphilis and HBV place our studied population among countries with highest prevalence of conducting such screening, on the other hand RV screening place its among countries with lowest prevalence. There is an increasing trend in conducting HIV screening but there are still reports of MTCT which are an examples of insufficient coverage of the screening. Screening for HCV and toxoplasmosis are, in the authors opinion, at satisfactory level. It is worth to acknowledge that Poland is one of a few European countries conducting such screening in general population of pregnant women. The screening for GBS is insufficient which, in our population, could possibly result in excessive use of intrapartum antibiotic prophylaxis.

\section{REFERENCES}

1. Rozporządzenie Ministra Zdrowia z dnia 20 września 2012 r. w sprawie standardów postępowania medycznego przy udzielaniu świadczeń zdrowotnych z zakresu opieki okołoporodowej sprawowanej nad kobietą w okresie fizjologicznej ciąży, fizjologicznego porodu, połogu oraz opieki nad noworodkiem. Dz.U. nr 12: 1100.

2. European Centre for Disease Prevention and Control. Antenatal screening for HIV, hepatitis B, syphilis and rubella susceptibility in the EU/EEA. Stockholm: ECDC; 2016.

3. "Profilaktyka infekcji HIV i zwalczanie AIDS na Mazowszu” Raport Zespołu ds. realizacji Krajowego Programu Zapobiegania zakażeniom HIV i Zwalczania AIDS w województwie mazowieckim, Warszawa 2014.

4. UNAIDS. UNAIDS report on the global AIDS epidemic. Geneva, 2013.

5. Narodowy Instytut Zdrowia Publicznego, Państwowy Zakład Higieny, "Zakażenia HIV i zachorowania na AIDS w Polsce w 2015 roku". http:// wwwold.pzh.gov.pl/oldpage/epimeld/hiv_aids/index.htm (2016.08.16).

6. Volmink J, Marais B. HIV: mother-to-child transmission. BMJ Clin Evid. 2008; 2008, indexed in Pubmed: 19450331.

7. Lee C, Gong Y, Brok J, et al. Effect of hepatitis B immunisation in newborn infants of mothers positive for hepatitis B surface antigen: systematic review and meta-analysis. BMJ. 2006; 332(7537): 328-336, doi: 10.1136/bmj.38719.435833.7C, indexed in Pubmed: 16443611.

8. Sieroszewski P, Bober Ł. Kłosiński. Zakażenia podczas ciąży. Perinatologia, Neonatologia i Ginekologia. 2012; 5: 65-84.

9. Bruś-Chojnicka A, Marszałek A, Moskalik M, et al. Problemy związane z zakażeniem wirusem HBV w kontekście prokreacji i życia seksualnego kobiety. Nowiny Lekarskie 2011; 80(4): 295-298.

10. Aniszewska M, Kowalik-Mikołajewska B, Pokorska-Lis M, et al. Częstość występowania przeciwciał anty-HCV u kobiet ciężarnych. Analiza czynników ryzyka zakażenia HCV. Przegl Epidemiol. 2009; 63: 293-298.

11. Kołakowska A, Godzik P, Madaliński K. Zakażenia wirusem HCV u kobiet w ciąży. Med Dośw Mikrobiol. 2014; 66: 215-222.

12. Chakraborty R, Luck S. Syphilis is on the increase: the implications for child health. Arch Dis Child. 2008; 93(2): 105-109, doi: 10.1136/adc.2006.103515, indexed in Pubmed: 18208988.

13. Serwin A, Chodynicka B. Diagnostyka bezpośrednia kiły — współczesne standardy i kierunki badań. Przegl Epidemiol. 2006; 60: 795-801.

14. Lambert SR. Congenital rubella syndrome: the end is in sight. $\mathrm{Br}$ J Ophthalmol. 2007; 91(11): 1418-1419, doi: 10.1136/bjo.2007.117960, indexed in Pubmed: 17947261.

15. Janaszek-Seydlitz W, Bucholc B, Wysokińska T, et al. Stan uodpornienia populacji polskiej przeciw odrze, śwince i różyczce a szczepienia ochronne. Przegl Epidemiol. 2003; 57: 281-288.

16. Montoya JG, Liesenfeld O. Toxoplasmosis. Lancet. 2004; 363(9425): 1965 -1976, doi: 10.1016/S0140-6736(04)16412-X, indexed in Pubmed: 15194258.

17. Remington JS, McLeod R, Thulliez P, Desmonts G. Toxoplasmosis. In: Remington JS, Klein JO, (eds.), Infectious diseases of the fetus and newborn infant, $5^{\text {th }}$ edn. Philadelphia, Saunders, 2001, 204-346.

18. Kravetz JD, Federman DG. Toxoplasmosis in pregnancy. Am J Med 2005; 118(3): 212-216, doi: 10.1016/j.amjmed.2004.08.023, indexed in Pubmed: 15745715 .

19. Nowakowska D, Stray-Pedersen B, Spiewak E, et al. Prevalence and estimated incidence of Toxoplasma infection among pregnant women in Poland: a decreasing trend in the younger population. Clin Microbiol Infect. 2006; 12(9): 913-917, doi: 10.1111/j.1469-0691.2006.01513.x, indexed in Pubmed: 16882298.

20. Bigos M, Łysakowska M, Wasiela M. Zakażenia okołoporodowe o etiologii Streptococcus agalactiae. Post Mikrobiol. 2012; 51(4): 299-308.

21. Rekomendacje Polskiego Towarzystwa Ginekologicznego dotyczące wykrywania nosicielstwa paciorkowców grupy B (GBS) u kobiet w ciąży i zapobiegania zakażeniom u noworodków. Ginekol. Pol. 2008; 79: 221-223.

22. Kowalska B, Niemiec KT, Drejewicz H, et al. Częstość występowania kolonizacji paciorkowcami hemolizującymi grupy B kobiet ciężarnych i noworodków określona na podstawie badań przesiewowych u pacjentek Polikliniki i Kliniki Położnictwa i Ginekologii Instytutu Matki i Dziecka — badania pilotażowe. Ginekol Pol. 2003; 74: 1223-1227.

23. Brzychczy-Wloch M, Strus M, Pawlik D, et al. Narastanie stopnia kolonizacji kobiet w ciąży i noworodków przez Streptococcus agalactiae na obszarze Polski południowo-wschodniej. Medycyna Doświadczalna i Mikrobiologia. 2008; 60(1): 5-12. 